\title{
REFORMS IN BAHRAIN
}

Genuine democratization or strengthening autocracy through liberalization? Those critical to the country's reforms argue that there will be progress, but just enough to consolidate the king' s powerbase and improve his image, while isolating the opposition. 
TEXT: Anh Nga Longva

IT IS GENERALLY HOPED that when the aging rulers of the Gulf pass away, their successors will embark upon liberalizing the conservative politics of the region thus paving the way for democracy. In this expectation lies the assumption that liberalization necessarily leads towards greater democracy. But does it? The first generation shift in the Gulf took place in Qatar in I995 when Crown Prince Hamad Al Thani deposed his father to become amir. Since then he has taken a series of measures some of which undeniably qualify as liberalizing steps. He allowed for instance the creation on Qatari soil of the Qatari financed satellite TV-station Al-Jazeera. While famously outspoken and one of the most important broadcasters in the Middle East today, AlJazeera tactfully and consistently avoids dealing with internal Qatari affairs. Thus the freedom of expression that Hamad introduced with Al-Jazeera has had no impact on the Qatari sociopolitical system. But it did help the ruler win high international ratings; his reputation was further enhanced when in I999 Qatar held its first elections ever in which women were allowed to vote and stand for office. In the commotion entailed by the introduction of universal suffrage in a region where denial of political rights to women is the rule, it is often forgotten that the object of the vote was a 29-member municipal council with no political functions whatsoever. The art of liberalizing without impinging upon the old autocracy recently reached new heights in Bahrain: the amir, sheikh Issa Al Khalifa died in March I999 and was succeeded by his 50-year old son, Hamad. Unlike his namesake in Qatar, the new Bahraini ruler inherited a deeply troubled land. The tiny island of Bahrain, tucked away in the Gulf of Salwa between the Saudi landmass and the Qatari peninsula, was shaken by a continuous uprising (intifada) that peaked between I994 and I998. It left 40 dead, thousands of arrests and detentions and hundreds of exiles in a population of slightly more than half a million, of which only 406.000 are Bahraini citizens. ${ }^{2}$

The unrest was preceded by two years of peaceful popular petitioning for the return of the Constitution suspended since I975 and the abrogation of the State Security Law. The popular petition was signed by 25.000 citizens and formulated in a respectful manner, but sheikh Issa and his government refused to receive it, let alone enter into dialogue with the signatories. Furthermore, the initiative takers were arrested and jailed, most of them without trial. The problems that beset Bahrain 
reach well beyond the realm of politics, narrowly defined. They lie in social-structural fault lines dating back to 1782 when the Al Khalifas and their tribal allies crossed over from the mainland via Qatar and conquered Bahrain from the Persians. The conquerors were Sunni and of Bedouin stock, the Bahrainis were Shi' a and settled farmers. The Al Khalifas took over the farmlands, turned the native population into rightless labourers and treated Bahrain since then as conquered territory. ${ }^{3}$ There is an Al Khalifa at the head of almost every single public institution of some significance. The family rules with the support of wealthy Sunni citizens and a handful of privileged Shi' a. The Shi' a are in majority - estimations vary between 60 percent and 70 percent - but they are little represented either in the public or the private sector. They make up the poorest tier of the society, and are the prime victims of unemployment, one of Bahrain's major problems and biggest paradox, since the country imports foreign workers from East and West to be employed in all sectors. ${ }^{4}$

\section{The intifada and the opposition in exile}

The I990s were one of the darkest chapters in Bahrain's history. The country lived under the state of emergency declared in I957 and the I975 State Security Law empowered the Minister of Interior to detain political suspects for three years or more without trial. People were terrified to discuss anything that could be interpreted as remotely related to politics, and it was only within the safety of their homes that they ventured to express their opinions. Until the intifada erupted in 1994, Bahrain was on the surface a peaceful and placid place. This quietism contrasted with the island' s rich history of political activism of the I930s and I950s (Khuri I980), which upon independence in I97I led Bahrain to opt for the constitutional system. In I973 a Constitution was drawn up and the country's first National Assembly was elected, in which both leftist secularists and conservative religious forces were well represented. Despite their ideological differences the deputies were united in their common refusal to ratify the State Security Law. In

\section{The Shi' a are in majority, but they are little represented either in the public or the private sector.}

the stalemate that ensued, the amir decreed the dissolution of the National Assembly in August 1975. He also unilaterally suspended the articles in the Constitution requiring the election of a new assembly within two months. Bahrain's short experience with parliamentarism came to an abrupt end, and the country reverted to the autocratic rule of the amir, his brother the Prime Minister and other members of his family. The civil and political rights contained in the Constitution were eliminated, the rule of law was inexistent and the slightest criticism against the government led to arrest and incarceration without trial. At the same time, with the financial assistance of Saudi Arabia notably, the regime strengthened the support of the Sunnis and part of the Shi' ite establishment by giving them the means to enrich themselves. Many within the vocal opposition were gradually coopted, others left the country in self-exile. The regime also care- 
fully groomed its international image. Bahrain became home to the US Fifth Fleet and gained the reputation of being a faithful ally of the West. As the only Gulf society that consistently allowed the consumption of alcohol, it was also known as a "tolerant" society open to Western culture that compared favourably with its surrounding neighbours. The first signs of resurging unrest appeared in the early I980s. In 1979 Khomeini's revolution shook Iran and ignited a wave of political activism among the Shi' a in the Arab Gulf countries (Wright I995). In I982 a group of Bahraini Shi' a was arrested for allegedly plotting to turn Bahrain into an Islamic republic. Scores of Shi' a were rounded, imprisoned or sent into exile. Shi' ite associations inside Bahrain were closed down, public religious celebrations were monitored and curtailed. The reaction of the regime was arguably efffective in the short run, but the seeds of unrest among the Shi' a were already sown. A new generation of Shi' ite youths went to study in Qom and came back to spread messages about justice for the oppressed majority. The experience of age-old discrimination at the hands of the Sunni rulers, added to aspirations for modern parliamentary democracy, provided the Shi' a with a particularly potent political motivation. Although liberal Sunni Bahrainis also called for the return of the 1973 Constitution and democratization, it was the Shi' a who kept the intifada of the I990s going. It was also the Shi' a who bore the brunt of the authorities' wrath. Arrests, imprisonments and forcible exile continued throughout the I980s and I990s under the auspices of the State Security Law. Summary trials were carried out by the State Security Court where the viola- tion of the most elementary international fair trial standards gave rise to strong criticism and protests from various international human rights organisations. The myth of Bahrain as a haven of tolerance began to fade.

The opposition in exile played a critical role in this respect. They worked tirelessly to bring the situation inside Bahrain to the world's attention. The most influential opposition group, the London-based Bahrain Freedom Movement (вFM) was the channel through which detailed information about the arbitrary arrests and detentions reached the human rights organisations and other relevant forums. The вғм also actively lobbied with Western politicians in the hope that pressure exerted by them would have an effect on the regime in Manama. But the government remained inflexible: it consistently downplayed the significance of the unrest, and stuck to its description of the intifada as the work of marginal sectarian fanatics on Iran's payroll.

\section{King Hamad' s reforms}

By 1998 the hardline policy adopted by the authorities towards the uprising was beginning to bear fruit, but only at the price of filling the country's prisons and earning Bahrain widespread international condemnation. Furthermore, four years of continued and at times violent unrest threatened to impact negatively on the country' s economy. By the late I990s, Bahrain had developed a reputation of unstability and it seemed just a matter of time before private national and international investors left the island for safer places like Dubai. Clearly change was needed, if only for the sake of the establishment. When sheikh Hamad 
succeeded to his father hopes were high that he would put an end to the deadlock. The new amir did not disappoint these expectations. He quickly initiated a series of positive gestures: in 1999 he freed the first batch of some hundred political prisoners and announced plans to hold municipal elections in which women can both vote and stand as candidates. In January 200I he announced that a National Action Charter (mithaq al amal al watani) was in preparation and would be put to a referendum a month later. The Charter promised to reinstate constitutional rule, though with a significant change: instead of the unicameral National Assembly envisaged by the 1973 Constitution, the majlis al watani would now consist of two chambers: the elected Deputy Chamber (majlis al nuwwab) and the appointed Consultative Council (majlis al shura). The Charter also proposed that Bahrain be changed into a constitutional monarchy headed by a king and no longer an amir. 90 percent of the Bahrainis took part in the February $\mathrm{I} 6$ referendum and 98.4 percent voted in favour of the Charter. This near unanimity may surprise. After all, the intifada started as the result of the regime's unwillingness to accede to the popular petition. A central demand in this petition was the return of the 1973 Constitution and the parliamentary system as outlined in it. The bicameral organisation proposed in the National Action Charter departs importantly from the 1973 document, yet the Bahraini opposition threw its support behind the Charter. To understand how this was possible let us listen to the account by the BFM:

"The opposition forces were opposed to the ambiguous wording of the Charter and hence a meeting was convened on 8 February 200I between the Amir and four senior opposition figures [..]. The session was direct and the opposition figures questioned two issues: whether the 1973 Constitution will be the governing criteria and whether the upper chamber will ever have legislative powers. The Amir replied ' I give you my word as a gentleman that the 1973 Constitution will be the basis and that the upper house will only be for consultation' . The opposition figures requested that these affirmations be published in the media. And the Amir responded. He ordered the Justice Minister to publish a statement that appeared in the two daily newspapers (Akhbar Al Khalij and Al Ayyam) the next morning (9 February 200I) confirming that the 1973 Constitution will be the basis and that the upper chamber will be for consultation only. In good faith, the opposition forces rallied behind the Amir." (BFM 2I February 2002).

Some doubts were expressed but events in the following months relegated them to the background. Immediately after the referendum, the amir repealed the hated State Security Law and abolished the notorious State Security Court. He emptied the prisons of political prisoners, allowed most exiles to return home and promised to allow the rest back as soon as possible. Censorship was scrapped and for the first time Bahrainis found they were free to debate political issues and to form non-governmental organisations without being arrested, imprisoned or fired from their jobs. The amir even indicated he was willing to address long-standing problems such as corruption, unemployment and housing. Additional economic bonuses 
were handed out: an extra month's pay was decreed for state employees, and ad hoc assistance to some of the needy, orphans and widows was distributed. The government even issued a promise to compensate hundreds of Bahrainis for salaries lost while they were detained in connection with the political unrest of the I99os. All these measures and promises were issued within the few months between the February referendum and summer 200I. The breathtaking pace of these reforms left the Bahrainis in a state of up-beat optimism. The new ruler's popularity soared as the people felt a genuine wave of gratitude towards him. Bahraini society had been living under a total absence of freedom for as long as the average young Bahraini adult can remember. Fear, or at least constant vigilance, had been the rule especially over the past two decades. By a stroke of the pen, the amir has lifted the veil of suspicion and silence. Thanks to him, an intoxicating wind of freedom was blowing over Bahrain. Yet for many the euphoria was tinged with uncertainty because, as we shall see presently, the signals sent by sheikh Hamad were mixed. As time went by, uncertainty turned into confusion and eventually, in some circles, into outright scepticism.

\section{The politics of personal generosity}

2002 was the year the municipal and parliamentary elections were held. I will focus on the latter, which took place in October 2002. The confusion and scepticism mentioned above were brought into the open when the four major opposition groups ${ }^{6}$ decided to boycott this election. The boycott revealed that Bahraini opinion was deeply divided: alongside the genuine gratitude many felt towards the amir - by now the king - was an equally genuine unease with the way the reforms were unfolding. Part of the population held the view that the recent measures decreed by sheikh Hamad, no matter how welcome in the short term, were little more than a contingent occurrence: they depend entirely on the king's goodwill. Unless they become legally sedimented rights to which citizens are entitled under clearly spelled conditions - which most of the measures are

The new ruler's popularity soared as the people felt a genuine wave of gratitude towards him.

not - they can be stopped or reversed at any time. In short, the Bahrainis worried that if the king can give, the king can also take back. In addition, the opposition wanted to regain its previous active role: from being able to steer events during the darkest hours of the intifada they suddenly found themselves relegated to a reactive position. Initiative now lay with the king whose reforms gave the impression that they fulfilled all the opposition's most basic demands. But these decisions are not presented as the result of the intifada. In the official narrative of the role of the Bahraini people, their demands and their sacrifices are not mentioned; rather the reforms are depicted as owed entirely to the king' s boundless generosity and his exceptional noble character (makramah). This presentation could have been dismissed as just a source of mild irritation if the reforms and generous handouts had been 
accompanied by genuine change in the power structure and the state apparatus. But so far such a change has not taken place. The king still governs the country with the assistance of his uncle, the Prime Minister, his son the Crown Prince, an appointed cabinet of ministers and an appointed Consultative Council. Al Khalifas still occupy half of the positions in the cabinet. The problem of lack of central democratic institutions has not been addressed, there are for instance few judicial checks on the actions of the king and his government, and the courts are still subject to government pressure. The individuals responsible for gross human rights abuses during the intifada have not been called to account, punished, or even removed from office. 'The policy of recruiting foreigners to work in the army, the police, and elsewhere is not only continuing: foreign military personnel and policemen - all of whom are Sunni Muslims are granted Bahraini citizenship by the thousands in spite of the Shi' a's angry claims that this is a strategy to upset the sectarian balance within the population. The only major institutional change introduced by the king so far is the issuance of the new constitution to replace the 1973 one.

The reader will recall that in early February 200I sheikh Hamad promised to the opposition that the 1973 Constitution would not be supplanted by the National Charter and would remain the basic document of the state of Bahrain. Soon after, however, the king proceeded to its unilateral amendment. According to Article I04 of the 1973 Constitution any constitutional amendments must be approved by the National Assembly and the Head of State.
The Assembly was dissolved in I975; strictly speaking, it should have been reinstated so as to be in position to decide upon the proposed amendments. Sheikh Hamad bypassed this procedure and the constitutional committee, appointed by him, reported only to him. Few citizens, whether loyal to the regime or oppositional, were informed or consulted under the process. When the new Constitution was officially announced on February I4, 2002 it was a fait accompli. Technically, one may say that sheikh Hamad had carried out a coup d' Etat and the Bahraini people had no choice but to go along with the outcome of the coup. The single major change promulgated in the new Constitution is the establishment of the bicameral system, something Bahrainis were prepared for and in favour of when they voted in the 200I referendum. What they had not expected was to see the appointed Consultative Chamber be invested by the new Constitution with the power to legislate on a par with the elected Deputy Chamber. It was arguably the blatant way in which the king reneged upon his promise given the year before that led the opposition to boycott the parliamentary election. Admittedly, the decision was controversial even among the leading members of the opposition. Some feared that this would result in their political marginalization and that the Deputy Chamber would be left entirely under the control of pro-government forces. But this was a minority view.

According to the official media and government sources, the turnout on Election Day was 53.2 percent. Compared to the turnout at the 200I referendum - 90 percent - and the overwhelming vote in favour of the Charter - 98.4 percent the difference is striking indeed, and it 
begs the question: What happened to the enthusiasm that fired the Bahraini people a mere I8 months earlier? And why has not the king's generosity since then helped keep this enthusiasm alive? The answer points to the constitutional amendments: they have led many to question the motives behind the reforms and to lose faith in their democratizing effect.

\section{Democratization or reforms to end all reforms?}

Supporters of the new Constitution argue that the bicameral system will enhance the balance between extreme political tendencies and prevent the radicalization of politics to which a single Chamber would, they believe, inevitably lead. The argument goes as follows: if the deputies are liberals and leftists, the king appoints a conservative in order to counteract the deputies' radicalism. If, on the other hand, the deputies are in majority Islamists, as is the case today, the king appoints a religiously moderate and even secularist Shura. If anything, this argument clearly shows that, in the present Bahraini context, the sole raison d' étre of the Consultative Council is to allow the ruler to always have the upper hand: whatever the composition of the elected Chamber, the deputies' attempts at passing laws that do not please the government can always be voted down by a Shura that is handpicked by the ruler and whose members are dismissed or reappointed by him every four years.

The reforms in Bahrain are too recent to allow a conclusive analysis. After years of repression and conflicts, Bahrainis understandably yearn for stability and reconciliation. This yearning leads many to interpret the ongoing events positively, viewing the contradictory signals sent out by the regime as inevitable hurdles on the road to democracy. Those critical to the reforms reject this approach as self-delusion: the regime, they argue, is in the process of winning legitimacy at the expense of the people. There will be some progress in the immediate future, they predict, but just enough to consolidate the king's powerbase and improve his image, while isolating the opposition, both at home and abroad. The effects of this policy are readily observable: In some circles the opposition is already being criticized for being too inflexible and uncooperative and its demands for further genuine change are dismissed as unreasonable. In contrast, the regime, having done the necessary gestures - freeing political prisoners, granting universal suffrage, permitting elections - is capitalizing on its newly won reputation of goodwill and liberalism. Whereas a few years ago the future of the Al Khalifa dynasty was uncertain, the family has now regained popularity with at least half of the population. They seem ready to give the Al Khalifas' autocratic rule a new lease of life on the basis of reforms that allow Bahrainis the freedom to speak but not the right to truly participate in the political process. If this analysis is correct, autocracy in Bahrain has found its best ally in liberalization; concomitantly and paradoxically, liberalization is, in this case, the most effective roadblock to genuine democratization.

$$
\cdot f \cdot
$$

Anh Nga Longua works at the Department of Social Anthropology, University of Bergen. 
>> the ruler and his closest relatives.

ACKNOWLEDGEMENTS

Fieldworks in Bahrain in 1994, 1995 and 2002 were financed by the Norwegian Council for Research and the Faculty of Social Sciences, University of Bergen.

REFERENCES

Bahrain Freedom Movement. 2002. Newsletter. February 2002.

Human Rights Watch. 200I. «World Report 2000: Bahrain».

Khuri, Fuad I. 1980. «Tribe and State in Bahrain». Chicago and London: Univeristy of Chicago.

Wright, Robin. 1985. «Sacred Rage. The Wrath of Militant Islam». New York: Simon $\&$ Schuster.

${ }^{\mathrm{I}}$ Another Gulf country that has much experience in supporting internationally outspoken but internally "tactful" news media is Saudi Arabia: one of the most widely quoted Arabic language newspapers in Europe, Al Hayat, is owned by a Saudi prince. Furthermore, the Dubai-based Middle East Broadcasting Center (мвс) is planning to launch Al Arabiya, a 24-hour news channel which will compete with AlJazeera. Most of the funding will come from Saudi Arabia.

${ }^{2}$ The remaining are migrant workers from Asia, the Middle East and Western countries.

${ }^{3}$ Thus access to some of the 42 islands that make up Bahrain is barred to the citizens because they are the private properties of
${ }^{4}$ For example: The police is staffed in majority by Baluchis from Pakistan and the Bahrain Defence Force (BDF) enrols Syrians and Yemenis as soldiers.

'The Sunnis who took part in the opposition were few but they were important figures in Bahraini society. In majority secularists and professionals (lawyers, academics) they were among those who took the initiative for the 1992 popular petition for the return of constitutional rule.

${ }^{6}$ Political associations and groups are now allowed, but not political parties. The most influential among the four boycotting groups was the Shi' ite Al Wifaq, the present-day avatar of the Bahrain Freedom Movement.

${ }^{7}$ On the contrary a royal decree was issued in late 2002 which extends impunity to all government officials, civil servants and security and military officers, for abuses committed before the promulgation of the decree. 